\title{
A Nemzeti Adó- és Vámhivatal munkaerő-megtartó képességének vizsgálata egy speciális célcsoport körében
}

\section{MAGASVÁRI Adrienn ${ }^{1}$ - SZABÓ Andrea ${ }^{2}$}

\begin{abstract}
Az utóbbi években számos konferencia, elöadás, tanulmány foglalkozik a szervezetek munkaerő-megtartó képességének vizsgálatával. A tapasztalatok szerint a munkaerôpiac átrendeződése, a munkaerő nemzetközi migrációja, az egyes generációk közti problémák kezelése, az új generációk igényeinek megismerése mind a magán-, mind a közszféra számára hatalmas kihívást jelent. A tanulmány egy, a Nemzeti Közszolgálati Egyetem Rendészettudományi Karának Nemzeti Adó- és Vámhivatal által támogatott szakirányain 2012-2017 között végzett hallgatók körében folytatott felmérés eredményeit mutatja be. Egyrészt a tanulmány láttatni kívánja a néhány éve szolgálatba lépett fiatal pénzügyőrök vélekedéseit a szervezet munkaerö-megtartási képességét befolyásoló tényezókkel, a munkahely-változtatásban szerepet játszó okokkal kapcsolatban. Másrészt pedig e tanulságok lehetővé teszik a szervezetnek is, hogy feltérképezze, hogy milyen hosszan számithat ezeknek a fiataloknak a munkájára.
\end{abstract}

Kulcsszavak: generációk, motiváció, utánpótlás

\section{Bevezetés}

Az a tendencia már egy jó ideje megfigyelhető nemcsak a közszféra szervezeteinél, hanem a versenyszférában is, hogy a szakembergárda korösszetételét tekintve egyre inkább elidősödik, jelentős a fluktuáció, helyükre egyre nehezebb megfelelő kompetenciákkal rendelkező, hozzáértő munkatársakat találni. Ezt természetesen erőteljesen befolyásolja az utóbbi években a munkaerőpiac átrendeződése is. Magyarországon

MAGASVÁRI Adrienn, pénzügyőr alezredes, tanszékvezető-helyettes, tanársegéd, NKE Rendészettudományi Kar Vám-és Pénzügyőr Tanszék

Adrienn MAGASVÁRI, customs lieutenant colonel, deputy head of department, assistant lecturer, NUPS Faculty of Law Enforcement

https://orcid.org/0000-0002-3737-0246, magasvari.adrienn@uni-nke.hu

2 SZABÓ Andrea dr., PhD, pénzügyőr ezredes, tanszékvezető egyetemi docens, NKE Rendészettudományi Kar Vám- és Pénzügyőr Tanszék

Andrea SZABÓ, PhD, customs colonel, associate professor and head of department, NUPS Faculty of Law Enforcement https://orcid.org/0000-0002-8224-4089, szabo.andrea@uni-nke.hu 
a munkanélküliek aránya rekordalacsony szintre esett vissza, a foglalkoztatottsági ráta pedig folyamatosan emelkedik. ${ }^{3}$ Mindezt erősíti még a munkaerő nemzetközi migrációja, illetve a foglalkoztatottság szerkezeti problémája, vagyis a hiányszakmák megjelenése is. ${ }^{4}$

A közszolgálati szervezeteknél ezt a helyzetet súlyosbítja, hogy a fiatal munkavállalókat, pályakezdőket egyre nehezebb a közigazgatási és rendészeti szervekhez vonzani. De még ha ez sikerül is, folyamatosan növekszik a fiatal korosztályhoz tartozók aránya a szervezeteket elhagyó munkatársak között. ${ }^{5}$ A jövő közszolgálatának hatékonysága és versenyképessége tekintetében tehát kulcskérdés, hogy a közszféra szervezetei képesek-e a kvalifikált, tehetséges fiatalokat a közszolgálatba vonzani és hosszú távon meg is tartani őket. Hiszen a fiatalabb korosztály megjelenése a munkaerőpiacon a közszolgálati szervezetektől is alkalmazkodást igényel.

Jelen kutatásunk egy speciális csoport Nemzeti Adó- és Vámhivatal (NAV) szervezetében „maradási” hajlandóságának vizsgálatára irányul. A felmérés alanyai jórészt az Y, kisebb mértékben a Z generációhoz ${ }^{6}$ tartozó fiatalok, akik 2-6 éve a Nemzeti Közszolgálati Egyetem Rendészettudományi Karának (NKE RTK) vám- és jövedéki igazgatási vagy pénzügyi nyomozói szakirányán végeztek, és a NAV-ban kezdték meg hivatásos szolgálati jogviszonyukat. Hogy miért inkább a megtartásukkal és nem a toborzásukkal (kiválasztásukkal) foglalkozunk? Részben azért, mert speciális helyzetükből adódóan az ő toborzásuk és kiválasztásuk már a felsőoktatási tanulmányaik megkezdésekor megtörténik, ez tehát nem a NAV hatásköre. A másik indokunk pedig egy konferencia-előadás keretében elhangzott, ennek a felmérésnek a lefolytatását és a tanulmánynak a megírását is inspiráló gondolat, miszerint: „az új toborzás a megtartás”.

\section{De mit is jelent az emberi erőforrás megtartása?}

A munkaerő megtartásának nincs egy általánosan elfogadott definíciója. Nehéz is lenne ezt egy gondolatban összegezni, hiszen a megtartás több emberi erőforrás-gazdálkodási funkcióhoz kapcsolódik. Azok múködése vagy hiánya egyaránt befolyásolja egy szervezet munkaerő-megtartó képességét. Hatással van a munkatársak szervezetben maradására tehát a belső motiváció, amelynek kialakulásában három tényezőnek ${ }^{8}$ van a legfontosabb szerepe: az önállóságnak, a szakmai igényességnek (ez alatt elsősorban a fejlődés, az egyéni fejlesztés, a jobbá válás iránti igényt értjük), illetve a céltudatosságnak (szervezeti célok közvetítése, ismerete). De a megtartás szoros kapcsolatban áll az ösztönzésmenedzsmenttel, a karriermenedzsmenttel, a tehetségmenedzsment-

\footnotetext{
KSH: 77 ezer fővel dolgoztak többen, mint egy évvel korábban. Gyorstájékoztató - Foglalkoztatottság. 2017. Forrás: www. ksh.hu/docs/hun/xftp/gyor/fog/fog1706.html (2019. 01. 10.)

$4 \quad$ Krajcsák (2018) 38.

Csutorás (2016) 93.

6 Y generáció: 1980-1994 között születettek (jelenleg 25-39 évesek); Z generáció: 1995-2009 között születettek (jelenleg 10-24 évesek).

Bezerédy (2017)

$8 \quad$ Pink (2010) 103-174.
} 
tel, ${ }^{9}$ a teljesítménymenedzsmenttel, a vezetői szemlélettel, stílussal is. Egyes kutatók ${ }^{10}$ szerint azonban a munkaerő megtartását nagymértékben befolyásolja a munkatársak elégedettsége, azaz a munkában megtalált élmény ${ }^{11}$ és elkötelezettsége, vagyis az elégedettség okán kialakult innovatív, alkotó, értékteremtő magatartás a szervezeti célok megvalósulása érdekében. ${ }^{12}$

Ha egy munkahelyen nem üzemelnek jól a fent említett humán funkciók, illetve nem segítik a szervezeti múködést, az előbb-utóbb a megfelelő kompetenciákkal, tapasztalattal rendelkező, tehetséges munkatársak elvesztéséhez vezet. Egy kulcsember pótlásának költsége pedig akár kétszerese is lehet a távozó munkatárs éves fizetésének, ${ }^{13}$ és akkor még nem szóltunk a tudásvesztés kockázatáról, költségeiről. Az új és megfelelő munkatársak toborzása, kiválasztása, beillesztése, képzése tehát jelentős időt és anyagi, illetve emberi erőforrás-ráfordítást igényel.

A közszolgálati szervezetek számára a munkaerő megtartása tehát hatalmas kihívást jelent. Még inkább nehézséget okoz azonban az új generációk megjelenése a szervezetekben, jelen esetben az Y és $Z$ generációhoz tartozó munkatársak munkaelvárásainak, munkahelyi preferenciáinak kezelése, a lojalitásuk megteremtése.

\section{Az Y és a Z generáció munkahelyi elvárásai}

Az Y és $Z$ generáció tagjai számára már nem a korábbi generációk által preferált motivációs eszközök, hanem új motivátorok a fontosak, leginkább érdekes feladatokkal, atipikus foglalkoztatási formák alkalmazásával (távmunka, rugalmas munkaidő) és jó vezető-munkatárs kapcsolattal lehet megnyerni őket. ${ }^{14}$ Ezek a fiatalok elsősorban nem egyetlen szakma, hivatás betöltésére vagy úgynevezett nyugdíjas állásra vágynak: a munkahely számukra olyan, mint bármely használati tárgy, ha megunták, már nem felel meg az elvárásaiknak, lecserélik. ${ }^{15} \mathrm{~A}$ biztos munkahely inkább a tapasztalatszerzés és az egyéni fejlődésük miatt fontos számukra, amelynek birtokában később több lehetőséget kapnak arra, hogy még jobb munkahelyre kerüljenek. ${ }^{16}$ Valamennyi elkötelezettséget növelő tényező közül legfontosabbnak a munka és a magánélet közötti egyensúly megteremtését tartják. ${ }^{17}$ Szívesen dolgoznak csapatban, ha a munkatársaik is hasonlóan együttműködőek, a vezetők pedig példamutatók, folyamatos visszacsatolást adnak számukra. A példamutató vezetés mellett megfelelő bérezésre, érdekes és kihívást jelentő munkafeladatokra, valamint kreatív munkakörnyezetre vágynak. ${ }^{18}$

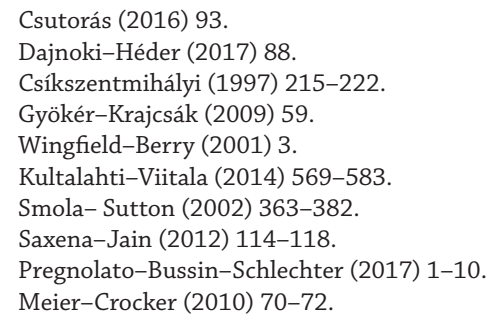


Az önbecsülésük sokkal erősebb, mint a korábbi generációké volt, ennek megfelelően jóval nagyobbak az elvárásaik is. Magasabb fizetést várnak, jó képzési lehetőségeket és gyorsan felfelé ívelő karriert szeretnének, mert sokszor túlbecsülik a saját teljesítményüket. ${ }^{19}$ Viszont készek rengeteget dolgozni, akár túlórázni is annak érdekében, hogy a „ranglétrán” feljebb lépjenek.

Persze ahhoz, hogy az Y és Z generációs fiatalok megtartását támogathassa a szervezet, azt is érdemes tudni, hogy vajon miért választják és milyen okok miatt hagyják el a fiatalok a munkaadó szervezeteket.

A PwC Magyarország a múlt évben közel 7000 középiskolában vagy felsőoktatási intézményben tanuló diák és pályakezdő munkahely-választási preferenciáit mérte fel. A felmérésben a megkérdezettek a rugalmas munkavégzést, az alapfizetést és a közvetlen munkatársaikkal való jó együttmúködést sorolták az első három helyre, azaz, ők ezen tényezők mentén választanak munkahelyet. A kutatási eredmények arra is rámutatnak, hogy az előbbieken kívül az Y és $Z$ generációs munkavállalók számára egyre fontosabb az a környezet, amely a munkahelyükön körülveszi őket (infrastruktúra, vezetők és munkatársak), a cafetéria és a távmunka lehetősége, valamint az őszinte és nyílt kommunikáció a vezetés részéről. ${ }^{20}$

„A versenyképes közszolgálat személyzeti utánpótlásának stratégiai támogatása” című projekt a „Pályakezdők beillesztését segítő mentori rendszer” alprojektje keretében végzett kutatás ${ }^{21}$ egyik kérdéskörében pedig kifejezetten a közszolgálati szervezeteket vizsgálta a pályakezdők pályaválasztását és pályaelhagyását befolyásoló tényezők vonatkozásában. A kutatás a rendvédelem, az államigazgatás és az önkormányzati igazgatás ágazataira terjedt ki, amelyben félig strukturált interjúk és kérdőíves adatgyüjtés módszerével dolgoztak a kutatók. A felmérésben részt vevők (közel 2000 fő) megítélése szerint a pályakezdők elsősorban azért választják a közszolgálati szervezeteket, mert biztos állást keresnek, illetve vonzza őket az érdekes munka és a szakmai fejlődés lehetősége. A kilépés legjellemzőbb okaiként pedig a versenyszféra elszívó hatását, az alacsony illetményt és a túlzott munkaterhelést említették a válaszadók. A kutatás alanyai szerint a legkevésbé a kihívást jelentő munkakör hiánya, valamint a vezetői stílus miatt hagyják el a szervezetet a pályakezdők. Ahogyan az látható, a két kutatás eredményei csak részben feleltethetők meg egymásnak. Ennek leginkább az az oka, hogy míg a PwC Magyarország felmérésében az érintett fiatalok véleményét kérdezték meg, addig a közszolgálati szervezetekben folytatott vizsgálatba a szervezetek vezetőit, továbbá olyan munkatársait vonták be, akik jellemzően nem a késői Y és a korai $Z$ generáció tagjai és az ő meglátásukat azért jelentősen befolyásolhatta, hogy más generáció tagjai, más szemlélettel, gondolkodásmóddal, elvárásokkal rendelkeznek.

Mivel az utóbbi években a NAV hivatásos jogviszonyba tartozó személyi állományának utánpótlását jelentős részben az NKE RTK két, NAV által támogatott szakirá-

19 Magasvári (2018b) 128.

20 Az idejük feletti erôsebb kontroll lehetôségét, magasabb fizetést és ôszinte kommunikációt várnak el a jövô munkavállalói (2018)

21 Magasvári-Szakács (2018) 184-204. 
nyán végzettek jelentik, úgy gondoltuk, az ő megtartásuk a jövőben is kulcskérdés lesz a szervezetben. Ezért a kutatásunkban is velük foglalkozunk.

Az NKE RTK - a jogelőd Rendőrtiszti Főiskolához hasonlóan - a hazai felsőoktatásban egyedüliként folytat rendészeti képzést. A kar a rendvédelmi szervek, így különösen a rendőrség, a Büntetés-végrehajtási Szervezet, a NAV, az Országos Katasztrófa-védelmi Főigazgatóság, továbbá a Bevándorlási és Menekültügyi Hivatal és a magánbiztonsági szféra számára képez hivatásos vagy civil munkakörök betöltésére alkalmas, felsőfokú állami iskolai végzettséggel rendelkező rendészeti szakembereket. A diplomás pályakövetési rendszer szerint a végzett hallgatók 98\%-a el tud helyezkedni. Ennek oka, hogy a hallgatók tanulmányi ösztöndíjszerződés birtokában tanulnak, azaz a szerződést aláíró szervek vállalják, hogy a diploma megszerzését követően alkalmazzák a végzetteket. ${ }^{22}$ Ebből is látszik, hogy a $98 \%$-os elhelyezkedési ráta nagyrészt az ösztöndíj-szerződésnek, továbbá a képzések egyediségének, speciálisan a megrendelő szerv igényeinek megfelelő felkészítésnek köszönhető.

Igaz ez a pénzügyőri alapképzést nyújtó szakirányok hallgatói esetében is, akiknek 1987 óta nyílik lehetőségük ilyen oktatásban részt venni, bár ekkor még csak vámnyomozó szak és levelező munkarend létezett. 1991-ben, a Vám- és Pénzügyőri Tanszék felállításával egyidőben indult el a vámigazgatási szak nappali és levelező munkarendben. Időközben persze a szakból szakirányok lettek, és az elnevezésük is megváltozott pénzügyi nyomozói és vám- és jövedéki igazgatási szakirányra ${ }^{23} 2009$-tôl pedig a pénzügyi nyomozói szakirány is megnyílt a külső pályázók számára, azaz, nappali munkarendben is választhatják ezt a képzést a hallgatók.

Az 1991-es első kibocsátás óta több mint 1400-an szereztek diplomát a fenti szakirányokon. Mindez azt jelenti, hogy korábban a Vám- és Pénzügyőrség, jelenleg pedig a NAV hivatásos állományának, mintegy 20\%-a a jogelőd Rendőrtiszti Főiskolán vagy a Rendészettudományi Karon végzett. ${ }^{24}$

A nappali munkarendű pénzügyőr hallgatók között végzett vizsgálat eredményei pedig arra utalnak, hogy a fiatalok pályaválasztását többségben céltudatos, tervszerü választás jellemzi. ${ }^{25} \mathrm{~A}$ szakirányok iránti érdeklődés tehát napjainkban továbbra is jól érzékelhető.

Amikor valakiúgy dönt, hogy a Nemzeti Közszolgálati Egyetem Rendészettudományi Karának valamely, a hivatásos életre felkészítő szakirányát választja, nagyon komoly elköteleződést vállal, hiszen nemcsak szakmát, hanem életmódot és hivatást is választ. Persze, nincs ezzel egyedül, hiszen hasonló megpróbáltatások elé néznek a katonai, ${ }^{26}$ de akár az orvosi pályát ${ }^{27}$ választók is.

\footnotetext{
22 A migrációs szakirány szintén ösztöndíj-szerződéssel működik, a biztonsági szakirányon végzettek elsősorban a civil személy- és vagyonvédelmi vállalkozások keretében, a természetvédelmi őrség szervezeteinél, a fegyveres biztonsági őrség, illetve a közterület-felügyelet egyes beosztásaiban helyezkedhetnek el.

3 Szabó (2017) 54.

24 Szabó (2018a) 71-80.

25 Erdős (2018) 12.

26 Kassai (2017) 2-11.

27 Vladár (2016) 17.
} 


\section{A pénzügyóri pálya megpróbáltatásai}

Már az egyetemi felvételi is jelentős stresszhelyzetnek számít, és emellett a képzés során olyan különböző nehézségek jelentkeznek, mint a tanulmányi ösztöndíj-szerződés jelentette kötöttségek, az alapkiképzés intenzív szakasza, az óralátogatási kötelezettség, az egyenruha viselése a képzés valamennyi fázisában és a nagymértékű óraterhelés mellett a rendészeti jellegú foglalkozások.

A felvételi eljárás menete - alapvetően - nem tér el a haza felsőoktatási rendszerben ismert és érvényes felvételi szokásoktól. A nappali képzések többsége azonban szigorú fizikai, egészségügyi és pszichológiai alkalmassági vizsgálathoz kötött. Bármelyik vizsgálat negatív kimenetele a jó tanulmányi eredmények elérése esetén sem teszi lehetővé a rendészeti képzésre történő felvételt.

A fizikai, egészségügyi és pszichológiai alkalmassági vizsgálat szabályai ${ }^{28}$ sok tekintetben megegyeznek a hivatásos állományú pénzügyőrök számára előírt elvárásokkal, ${ }^{29}$ mint ahogyan a felvételi eljárás is azonosságokat mutat a hivatásos állományba történő felvétel követelményeivel. A képzésre felvételt nyert személyeknek ugyanúgy hozzá kell járulniuk a kifogástalan életvitel ellenőrzéséhez, igazolniuk kell büntetlen előéletüket, és el kell fogadniuk, hogy ezt ellenőrizhetik. ${ }^{30}$ Továbbá majdhogynem ugyanolyan kötelezettségek is terhelik őket, mint a hivatásos állományú tagokat, azaz, a szigorú függelmi rend betartása, az alapjogok korlátozásának elfogadása, de akár az élet- és a testi épség kockáztatásával járó feladatellátás is. ${ }^{31}$

A hallgató az ösztöndíj-szerződés aláírásával vállalja, hogy rendészeti tanulmányait legjobb képességei szerint folytatja, ${ }^{32}$ hogy hivatásos állományba vételét követően legalább a rendészeti alapképzésnek megfelelő időtartamban a vele szerződést kötő szervnél szolgálatot teljesít. Amennyiben önhibájából szűnik meg a hallgatói jogviszonya, vállalja a képzés költségeinek visszatérítését. Vállalja továbbá azt is, hogy a diploma megszerzését követően a szerv igényeinek megfelelően - Magyarország közigazgatási területén belül - a számára meghatározott szolgálati helyet elfogadja. A NAV pedig arra kötelezi magát, hogy a hallgató rendészeti tanulmányait támogatja, illetve hogy a tanulmányok befejezését követően a hallgatót hivatásos állományba veszi, és a végzettségének megfelelő munkakörben foglalkoztatja.

A fentiekben leírtak kapcsán felvetődhet a kérdés, hogy biztosan érti-e és tudja-e az a fiatal, aki az ösztöndíj-szerződést aláírja, hogy mit vállal? Mártonffy Károly a közszolgálat jellemzőinél kiemeli, hogy a pályának egész életre szólónak kell lennie, illetve

\footnotetext{
28 57/2009. (X. 30.) IRM-ÖM-PTNM együttes rendelet az egyes rendvédelmi szervek hivatásos állományú tagjai egészségi, pszichikai és fizikai alkalmasságáról, közalkalmazottai és köztisztviselői munkaköri egészségi alkalmasságáról, a szolgálat-, illetve keresőképtelenség megállapításáról, valamint az egészségügyi alapellátásról.

29 73/2013. (XII. 30.) NGM rendelet a Nemzeti Adó- és Vámhivatalnál foglalkoztatottak alkalmassági vizsgálatáról, valamint a Nemzeti Adó- és Vámhivatal Képzési, Egészségügyi és Kulturális Intézete által nyújtott egészségügyi szolgáltatás igénybevételére jogosultakról.

30 Szabó (2018b) 601-602.

31 Magasvári (2018a) 46.

32 Elvárt eredmény a minimum 3,0 súlyozott tanulmányi átlag.
} 
a köz érdekében cselekvőnek egész szellemi erejét a szolgálat rendelkezésére kell bocsátani. ${ }^{33} \mathrm{Az}$ elmúlt évek oktatói tapasztalataira építve úgy véljük, hogy a (többségében tizennyolc éves) fiatalok, éppen kikerülve a gimnázium padjaiból, nem feltétlenül értik a fenti mondat jelentőségét, és egyáltalán nem biztos, hogy életre szóló hivatásra vágynak. Pedig ezeknek a fiataloknak már hallgatóként is tisztában kellene lenniük azzal, hogy hogyan szolgálhatják leginkább a szervezeti érdekeket, el kell köteleződniük a NAV irányába. A szervezetnek pedig arra kell figyelnie, hogy a képzés befejezését követően megfelelően beillessze őket a szervezetbe, és olyan módon motiválja őket, hogy hosszú távon megmaradjanak ebben hivatásban.

A fentiekből kiderül, hogy az időnyomás (kötött órarend, vizsgák tucatja félévente) és a kudarctól való félelem (sikertelen vizsgák, amelyek a szerződés felbontásához vezethetnek), a lojalitás kényszere (mindenképpen a NAV-ban kell dolgoznia, ha a tartozást nem tudja visszafizetni) stresszorként jelentkezhetnek. Egy az orvostanhallgatók körében végzett kutatás következtetései megerősítik a fentiekben leírtakat, így „a szoros időbeosztás megszervezése újszerű feladatként jelentkezhet a hallgatók életében [kötelező óralátogatás, létszámellenőrzés, zárthelyi dolgozatok, vizsgák torlódása], ha életük minden területére szeretnének elegendő időt fordítani. Emiatt fontossági sorrend felállítása válik szükségessé” ${ }^{34}$ A szakmai gyakorlatok során és a pályakezdés időszakában a beilleszkedés nehézségeivel kell megküzdeniük, „a csapatmunka nehézségeit kell elsajátítani, miközben a hierarchia alján helyezkednek el”. ${ }^{35}$

\section{A kutatás módszertana}

Kutatásunk célja az volt, hogy feltárjuk az NKE RTK vám- és jövedéki igazgatási, továbbá pénzügyi nyomozói szakirányain végzett hallgatók attitűdjeit, vélekedéseit a szervezetek munkaerő-megtartási képességét befolyásoló tényezőkkel, a jelenlegi munkahelyük (68 kitöltő esetében a NAV) munkaerő-megtartó képességének mértékével, a leginkább maradásra vagy távozásra ösztönző jellemzőkkel kapcsolatban. Másfelől, szerettünk volna arra is választ kapni, hogy a NAV létrejöttét követően végzett hallgatók közül vajon hányan döntöttek úgy, hogy máshol keresik a jövőbeni boldogulásuk kulcsát, illetve milyen okok motiválták őket a munkahely változtatásban, milyen típusú szervezetben helyezkedtek el. Szerettünk volna továbbá arról is képet kapni, hogy a fiatalok milyen jövőbeni tervekkel rendelkeznek a karrier, illetve a munkahely kapcsán, élethivatásként tekintetnek-e a pénzügyőri pályára vagy a későbbiekben más munkahelyen is szívesen kipróbálnák magukat.

A kutatási célok elérése érdekében az alábbi négy területet vizsgáltuk meg kérdőíves módszerrel:

1. szervezetek munkaerő-megtartó képességét befolyásoló tényezők fontosság szerinti vizsgálata;

\footnotetext{
Molnár (1993) 22.

Vladár (2016) 17.

35 Vladár (2016) 17.
} 
2. a jelenlegi munkahely munkaerő-megtartási képességének mértéke, a maradást, illetve a távozást leginkább befolyásoló tényezők vizsgálata;

3. a szervezetből való kilépés okainak vizsgálata;

4. a jövőbeni karriertervek vizsgálata.

A vonatkozó korábbi empirikus kutatási eredmények, valamint a hazai és nemzetközi szakirodalom alapján az előzőekben ismertetett vizsgálati szempontokat érintően a következő hipotéziseket fogalmaztuk meg:

H1 - Feltételeztük, hogy a vizsgálatban részt vevő Y és $Z$ generációs fiatalok NAVban való maradási hajlandóságát - hasonlóan a magánszférában végzett kutatások ${ }^{36}$ eredményeihez - nem azok a tényezők motiválják, mint amit a korábbi generációk esetében tapasztalhattunk (H1A). Elsősorban nem a munkahely biztonsága, a nyugdíjig tartó állás lehetősége vagy az adott szervezet társadalmi megítélése miatt választják a NAV-ot, illetve maradnak hosszabb ideig ebben a szervezetben, hanem új motivátorok (például munka és magánélet összehangolása, személyes és fizikai munkakörnyezet) fontosak a számukra (H1B).

H2 - Feltételeztük, hogy ha munkahelyváltásra kerül sor, akkor elsősorban a magasabb illetmény reményében hagyják el a szervezetet, és jellemzően a magánszektorban helyezkednek el.

H3 - Feltételeztük, hogy a munkahelyváltásra jellemzően a tanulmányi ösztöndíjszerződésben előírt, a NAV-ban kötelezően eltöltendő időtartam (3 év) leteltét követően került sor (H3A), és befolyással bír erre, ha a pályakezdő - kinevezését követően - nem arra a szolgálati helyre került, ahová szeretett volna (H3B).

A kutatással érintettek köre a Nemzeti Közszolgálati Egyetem Rendészettudományi Karán - 2012 és 2017 között - vám- és jövedéki igazgatási és pénzügyi nyomozói szakirányon végzett és a diploma megszerzését követően a NAV hivatásos szolgálati jogviszonyában foglalkoztatott személyi állomány, természetesen az azóta távozottakkal együtt.

A kiválasztás alapja, hogy az érintett személyi kör a diploma megszerzését követően már a NAV állományába került, még a hároméves képzésben vett részt, ${ }^{37}$ és még nem tisztjelölti státuszban ${ }^{38}$ kezdte meg a tanulmányait. Ennek megfelelően a tanulmányi ösztöndíj-szerződésük is azonos követelményeket tartalmazott, így a kötelezően vállalt szolgálati idő a NAV szervezetén belül a hároméves időtartam, amely a képzési időnek felel meg. A megtartóerőt vizsgálva, ennek az időtartamnak a későbbiekben jelentősége lehet. A 2016-ban felvett tisztjelöltek ugyanis már hat évet, a 2017-től négyéves képzésben részt vevők pedig nyolc évet írnak alá a szerződésükben. A kiválasztás további feltétele volt, hogy nappali munkarendben végezze a tanulmányait, hiszen a le-

\footnotetext{
36 A global generational study, 2013. Summary and compendium of findings (2013); What if the next big disruptor isn't a what but a who? Gen $\mathrm{Z}$ is connected, informed and ready for business (2015)

372017 szeptemberétől a nappali munkarendű képzés 4 évre növekedett.

382016 szeptemberétől bevezetett új hallgatói jogviszony.
} 
velező munkarendű hallgatók már eleve a NAV hivatásos állományából kerülnek ki. Ök jelentették tehát az alapsokaságot.

A kutatás során valószínúségi mintavételi eljárással dolgoztunk és a teljes vizsgált populációt igyekeztünk megkeresni, azaz esetünkben az alapsokaság (158fő) és a minta (156 fő) elemszáma szinte teljes mértékben megegyezett. A felmérés során kérdőíves adatgyưjtés módszerével dolgoztunk, mivel más kutatási módszerek alkalmazásához nagy volt a minta száma, illetve ezzel a felméréssel tudtuk biztosítani az önkéntességet és az anonimitást, így bíztunk abban, hogy a válaszadási hajlandóság is nagyobb lesz. Ez a módszer megadta azt a rugalmasságot is, hogy a felmérés időszakában minden megkérdezett szabadon dönthetett arról, hogy mikor és hol kívánja kitölteni a kérdőivet.

A kérdőív kitöltését végül 79 fő vállalta, a nemek arányát megvizsgálva azt láthatjuk, hogy 51 férfi és 28 nő válaszolt a kérdésekre. A NAV-hoz felvettek esetében ez a szám 109 férfi és 49 nő, amely arra utal, hogy a kitöltők és a felvettek nemek szerinti megoszlásának aránya szinte teljesen megegyezik. Ha megvizsgáljuk a felvettek és válaszadók arányát a diplomaszerzés éveinek függvényében, azt látjuk, hogy minden évfolyamból szinte 50\%-os volt a válaszadási hajlandóság és ez az arány az összes válaszadóra is igaz, ahogyan ezt az alábbi táblázat mutatja:

1. táblázat: A NAV-hoz felvettek és a válaszadó aránya a diplomaszerzés évének függvényében. Forrás: a szerzök szerkesztése

\begin{tabular}{|c|c|c|c|}
\hline Diplomaszerzés éve & Felvettek száma & Válaszadók száma & Arány \\
\hline 2012 & 30 & 12 & $40 \%$ \\
\hline 2013 & 31 & 14 & $45,1 \%$ \\
\hline 2014 & 18 & 11 & $61,1 \%$ \\
\hline 2015 & 26 & 13 & $50 \%$ \\
\hline 2016 & 21 & 10 & $47,6 \%$ \\
\hline 2017 & 32 & 18 & $56,2 \%$ \\
\hline
\end{tabular}

A kutatásban részt vett személyek demográfiai jellemzőit, valamint a feltett kérdéseket az alábbiakban ismertetjük.

A válaszadók közül 33 fő vám- és jövedéki igazgatási, 46 fő pedig pénzügyi nyomozói szakirányon szerzett diplomát. A válaszadók szolgálati és munkahelyét elemezve azt látjuk, hogy 40 fő a fővárosban, 30 fő megyeszékhelyen, 3 fő más nagyvárosban, valamint 4 fő kistelepülésen dolgozik. Mivel a munkahelyi megtartóerő egyik fontos eleme a munkavállaló által preferált szolgálati hely elnyerése lehet, ezért a kérdésre, hogy az általa preferált szolgálati helyre került-e, 57 fő igennel válaszolt, ezen belül 57 fő úgy nyilatkozott, hogy inkább igaz rá, hogy oda került, ahová szeretett volna. 22 fő nem az általa elképzelt vagy számára elfogadható helyre került.

A válaszadók közül 11 fő már nem áll foglakoztatási jogviszonyban a NAV-val, közülük 4 fő 1 éven, 1 fő 2 éven, továbbá 3-3 fő pedig 3 éven belül, valamint 3 éven túl hagyta 
el a szervezetet. Ha a nemek arányát nézzük, 8 férfit és 3 nőt találunk a távozók között, egy férfi az, aki munkahelyet váltott és házasságban él, illetve gyermeket is nevel.

A szervezetet elhagyók közül legtöbben a fővárosban dolgoznak (5 fő), 3 fő megyeszékhelyen 1 fő más nagyvárosban és 2 fő kistelepülésen vállalt munkát. Közülük 1 fő közigazgatási szervnél, 2 fő rendvédelmi szervnél, 8 fő a versenyszférában helyezkedett el (ideértve azt az 1 személyt is, aki saját vállalkozásba kezdett). Ha megvizsgáljuk a távozók szakirányát, azt látjuk, hogy 6 fő a vám- és jövedéki igazgatási, míg 5 fő a pénzügyi nyomozói szakirányon végzett.

Ahogy az előre prognosztizálható a leszerelés mellett döntők nagyobb része (6 fő) nem az általa preferált szolgálati helyre került, ami jelentheti a szolgálati hely földrajzi vagy szakterületi eltérését a munkavállaló által elképzelttől. Azonban az is érdekes lehet, hogy a távozók közül 4 fő teljes mértékben az általa preferált, míg 1 fő az általa részben preferált szolgálati helyre került.

A kérdőívet kitöltők nagyobb része, összesen 68 fő még NAV-alkalmazott és közülük 36 fő ugyanott dolgozik a felvétele óta, míg 11 fő 1 éven belül, 8-8 fő 2 és 3 éven belül, és további 5 fő 3 év után szakterületet/munkakört/szolgálati helyet váltott.

\section{A kutatási eredmények}

A kutatás során kíváncsiak voltunk arra, hogy bizonyos munkahelyi, szervezeti múködéssel kapcsolatos jellemzőket, emberi erőforrás-gazdálkodással összefüggő funkciókat a munkaerő megtartása szempontjából mennyire tartanak fontosnak a pályakezdő fiatalok. A szervezet munkaerő-megtartását általánosságban befolyásoló tényezőket egy kilencfokozatú skálán értékelhették a válaszadók aszerint, hogy azt mennyire tartják fontosnak. Az összesített eredményeket az alábbi ábra mutatja: 


\section{Munkaerő-megtartó képességet befolyásoló szempontok - FONTOSSÁGI skála}

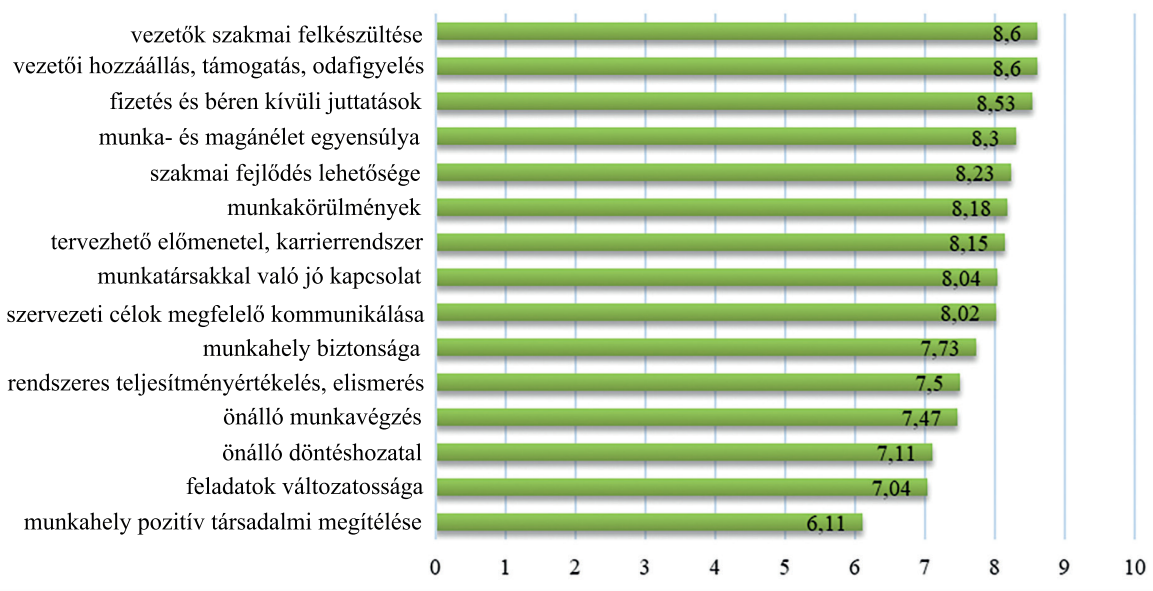

1. ábra: A szervezet munkaerō-megtartását általánosságban befolyásoló tényezők. Forrás: a szerzők szerkesztése

A kérdőívet kitöltők minden általunk megadott tényezőt inkább fontosnak értékeltek. Véleményük szerint azonban a három legfontosabb szempont, amely pozitívan hat egy szervezet munkaerő-megtartó képességére: a vezetők szakmai felkészültsége, a vezetői hozzáállás, támogatás és odafigyelés, valamint az illetmény és az egyéb juttatások. Szerintük egy számukra megfelelő munkahelyen gondoskodnak továbbá arról, hogy a munka- és magánélet egyensúlyban legyen, lehetőséget adnak a szakmai fejlődésre, megfelelőek az munkakörülmények (ideértve az infrastrukturális jellemzőket, a munkaidőt), tervezhető az előmenetel, és jól múködnek a munkahelyi kapcsolatok. Álláspontjuk szerint legkevésbé bír megtartó erővel a munkahely társadalmi megítélése, a feladatok változatossága, az önálló döntéshozatal és munkavégzés lehetősége, de a teljesítményértékelést, a munkahely biztonságát és a szervezeti célok megfelelő kommunikálását sem tartják kiemelten fontosnak. A fontossági sorrendben élen álló tényezők közül az illetményt, illetve a szakmai fejlődés lehetőségét, a munkakörülményeket, valamint a munka- és magánélet egyensúlyát és a munkatársakkal való jó kapcsolatot a korábban említett kutatások is kiemelték. Szemben azonban a közszolgálatban végzett felmérés eredményével, a munkahely biztonságát korántsem tartják olyan fontosnak a fiatalok, hogy emiatt válasszák a közszférabeli munkahelyeket.

A fontossági szempontokon túl azt is szerettük volna megtudni, hogy vajon ezek a tényezők (a kérdésben minden tényezőt egy-egy rá leginkább jellemző állításban fogalmaztunk meg) mennyire igazak arra az adott szervezetre, milyen mértékben múködtetik ezeket a funkciókat azokon a munkahelyeken, ahol a válaszadók jelenleg dolgoznak. Ennél 
a kérdéskörnél is egy kilencfokozatú skálán kellett megadniuk a kitöltőknek, hogy meglátásuk szerint mennyire igazak az állítások a munkaadó szervezeteikre. Mivel a válaszadók 86\%-a a NAV-val áll foglalkoztatási jogviszonyban, úgy véljük, az alábbi ábrán bemutatott eredmények a NAV jellemzőit is tükrözik.

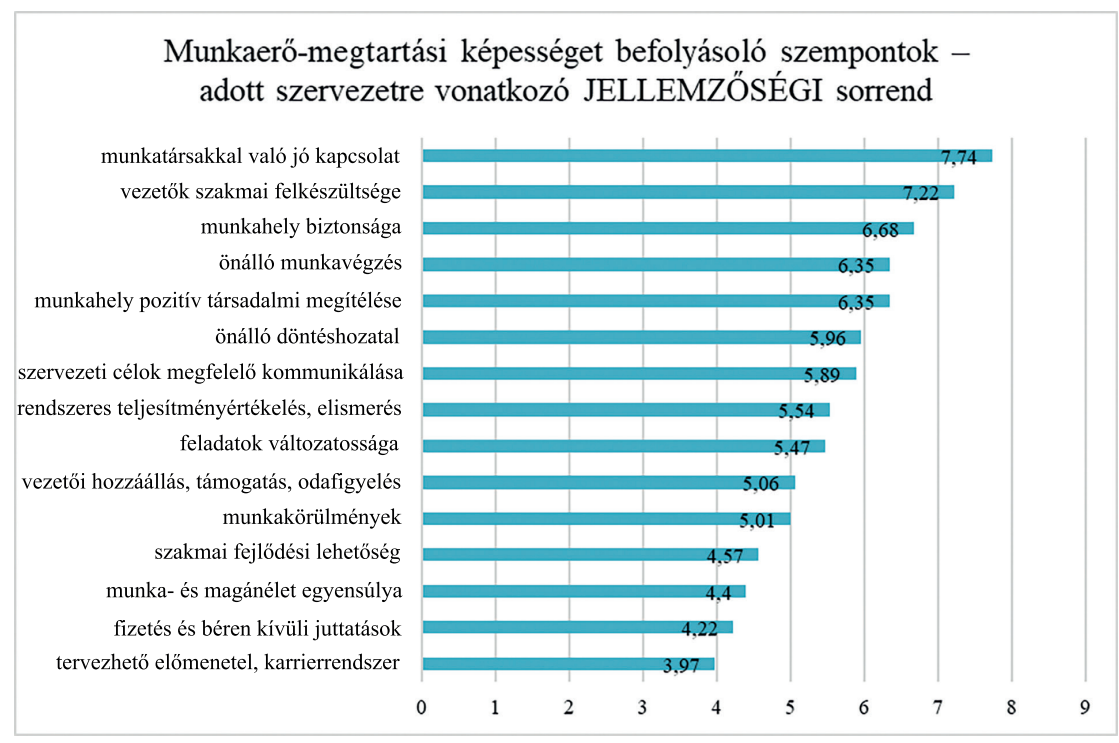

2. ábra: A munkaerö-megtartási képességét befolyásoló tényezők megléte a jelenlegi munkaadóknál. Forrás: a szerzők szerkesztése

Ahogyan az a fenti ábra alapján látható, az Y és Z generációs válaszadók szerint a munkaerő megtartását befolyásoló tényezők többsége sokkal kevésbé jellemző a jelenlegi munkaadó szervezetükre, mint amennyire azt fontosnak tartják. Úgy vélik, hogy a munkatársakkal való jó kapcsolat, együttmúködés, a vezetők szakmai felkészültsége és a munkahely biztonsága azok a tényezők, amelyek a NAV munkaerő-megtartó képességére leginkább jellemzőek, ezek átlag feletti értéket is kaptak. Ami a válaszadók szerint legkevésbé támogatja a fiatalok szervezetben való maradását az a jelenlegi karrierrendszer, a fizetés és az egyéb juttatások, a munka- és magánélet összhangjának, illetve a szakmai fejlődés lehetőségének hiánya. Ezek a tényezők meglehetősen alacsony átlagértékkel szerepelnek a listában.

A következő ábrán összevetettük, hogy a munkaerő megtartását befolyásoló szempontok mennyire elvártak és mennyire jellemzőek a munkaadókra, így a NAV-ra is. 


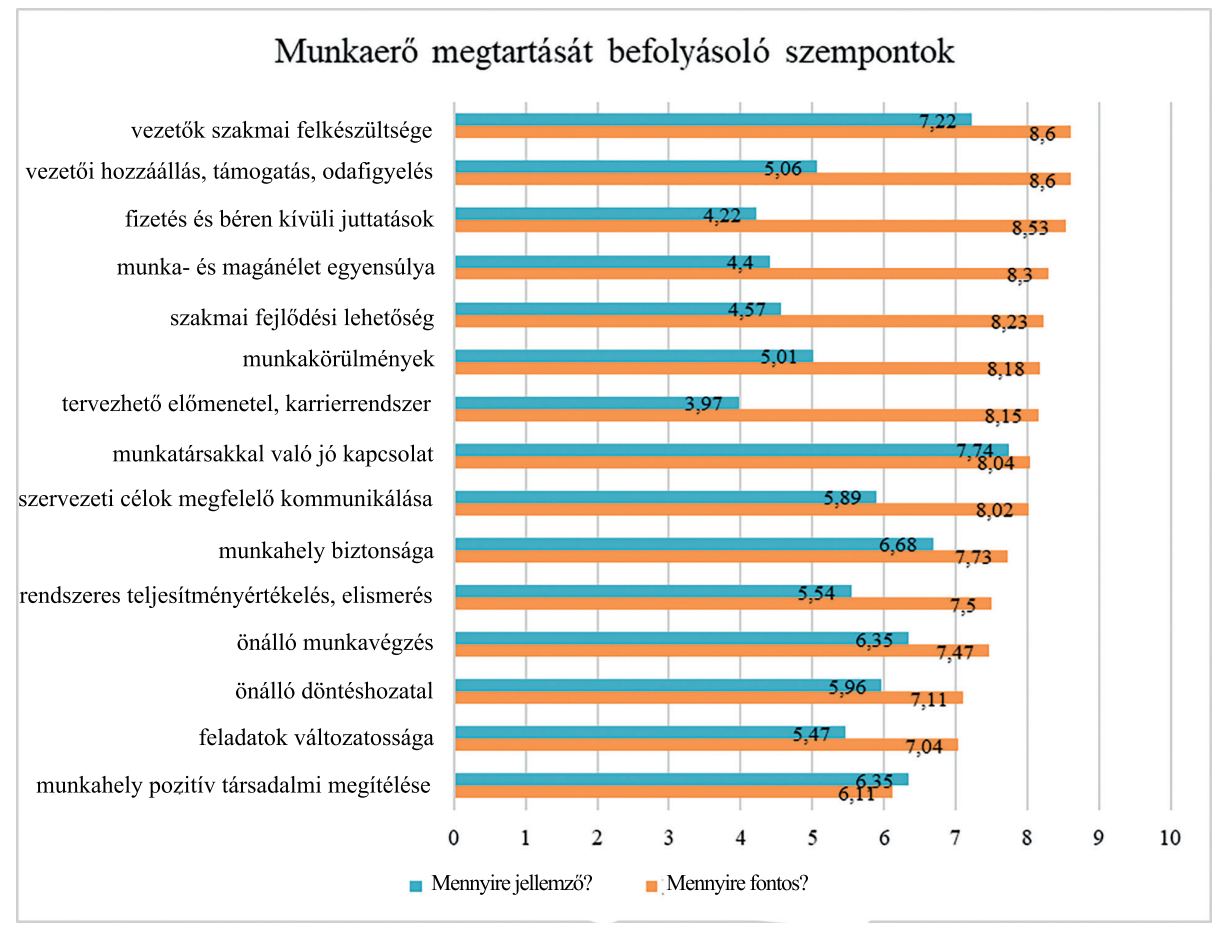

3. ábra: A munkaerő megtartását befolyásoló tényezők fontosság és jellemzőség szerint. Forrás: a szerzők szerkesztése

Pozitívan értékelhető, hogy a válaszadók szerint a munkatársakkal való jó kapcsolatot nemcsak elvárják a fiatalok, de a jelenlegi munkahelyükön szinte ugyanolyan mértékben tapasztalják is. A munkahely biztonsága, az önálló munkavégzés és döntéshozatal azok a szempontok, ahol szintén nem mérhető olyan éles eltérés az elvárt és a múködő jellemzők között. Az egyetlen szervezeti ismérv, amelyet magasabbra értékeltek a kitöltők, mint amennyire fontosnak tartják, az a munkahely pozitív társadalmi megítélése. A többi munkahelyi sajátosság nem közelíti meg azt a szintet, amit a pályakezdők elvárnak egy szervezetben. Különösen jelentős az eltérés a fizetés és a béren kívüli juttatások, a karrierrendszer, továbbá a munka- és magánélet egyensúlya, illetve a szakmai fejlődés lehetősége, a vezetői hozzáállás és a munkakörülmények tekintetében (több mint 3 pontos különbség).

Az előbbiek alapján megállapítható, hogy a munkaerő megtartása érdekében a NAVnak az alábbi szervezeti múködést érintő területeken vagy emberi erőforrás-gazdálkodási funkciók tekintetében kell változtatnia:

- ösztönzési és illetményrendszer,

- előrelépést, előmenetelt támogató életpálya, 
- munkaterhelés csökkentése a magánélet és munka összhangjának biztosítása miatt,

- képzési és fejlesztési lehetőségek biztosítása,

- vezetői stílus, szemléletváltás,

- munkakörülmények.

Ahhoz, hogy a NAV munkaerő-megtartó képességét erősíthesse, fontos ismernie, hogy akik távoznak a szervezetből, milyen okok miatt teszik ezt. Az alábbi grafikon ezt szemlélteti.

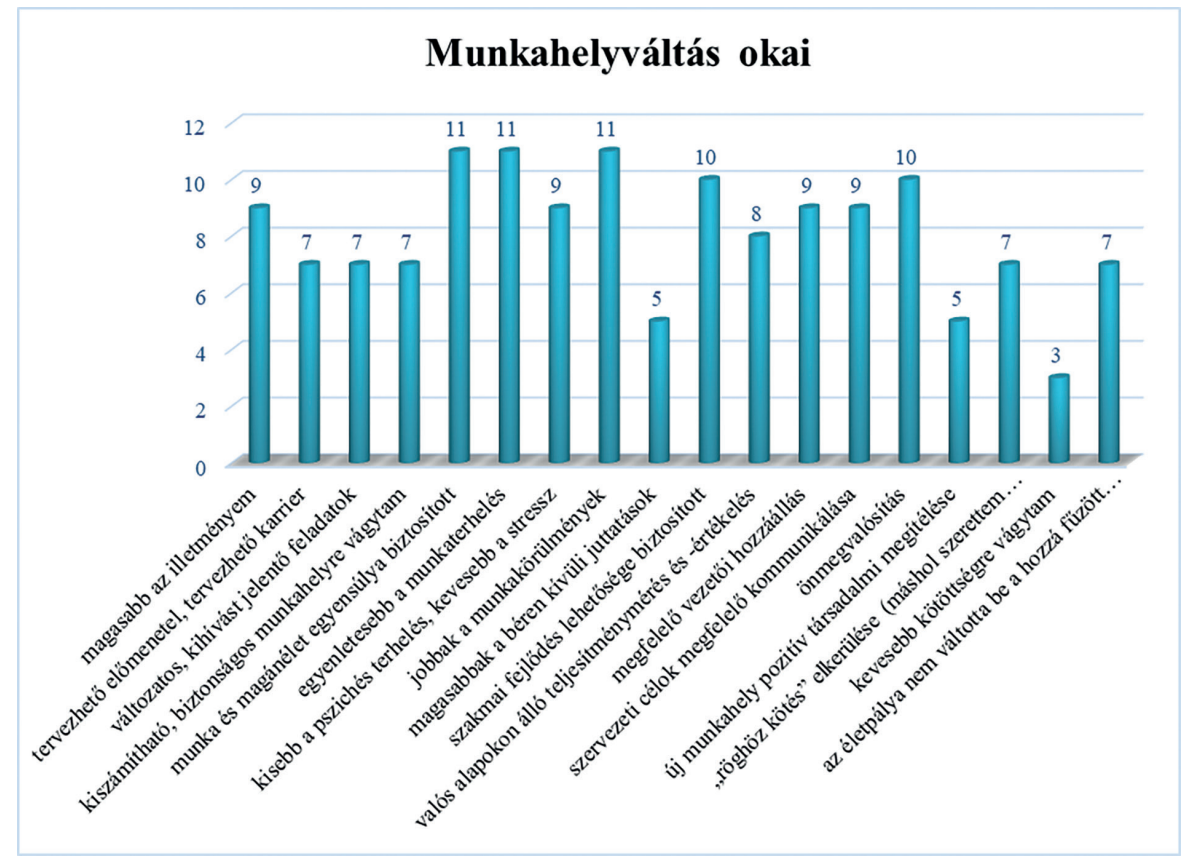

4. ábra: A munkahelyváltás okai. Forrás: a szerzők szerkesztése

A legjellemzőbb munkahelyváltási okok között nem a magasabb illetményt, hanem a jobb munkakörülményeket, az egyenletesebb munkaterhelést, illetve a munka és magánélet összhangját jelölték meg a válaszadók. Ezt követi a sorban a szakmai fejlődés lehetősége, illetve az önmegvalósítás. Legkevésbé vannak hatással a távozásra a béren kívüli juttatások, az új munkahely pozitív társadalmi megítélése, illetve a szervezeti hierarchiából eredő kötöttségek.

Ha a jelenleg a NAV-val hivatásos jogviszonyban álló fiatal munkatársakat hosszú távon szeretné a szervezet foglalkoztatni, érdemes odafigyelni a jövőbeni terveikre, munkahelyi elvárásaikra is. A következő ábra erre ad választ. 


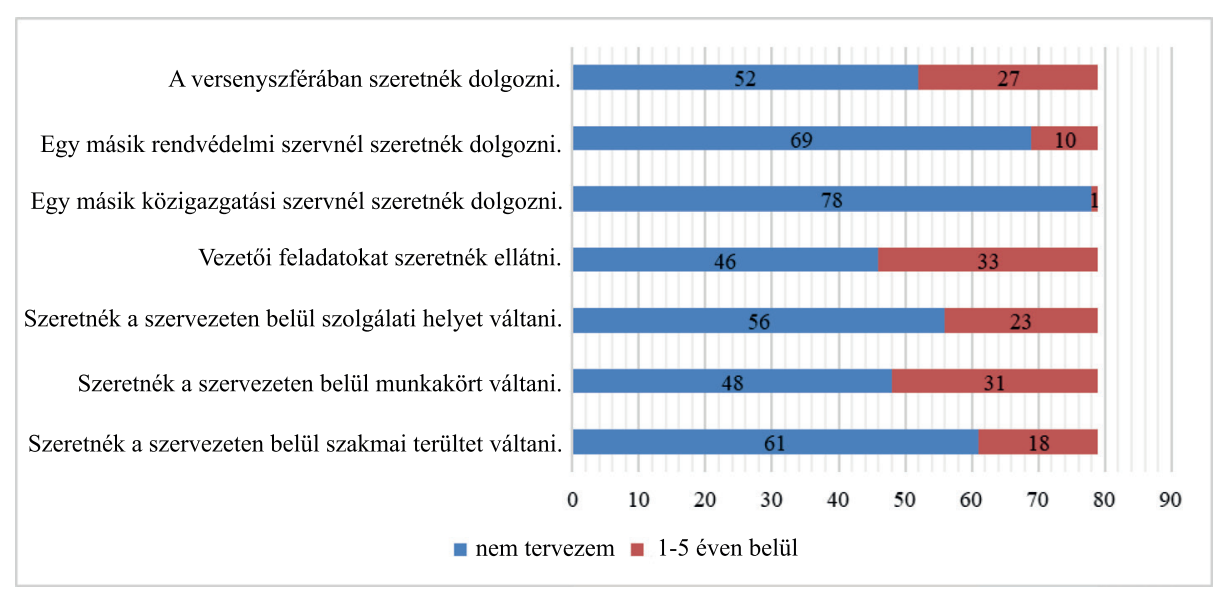

5. ábra: A pályakezdôk 1-5 éven belüli tervei. Forrás: a szerzők szerkesztése

Összességében a válaszadók 48\%-a gondolja úgy, hogy 5 éven belül elképzelhetőnek tartja a munkahelyváltást. Ők jellemzően a magánszektorban szeretnének elhelyezkedni. Ha esetleg maradnak a szervezetben, akkor is szívesen kipróbálnák magukat új munkakörben (39\%) vagy másik szolgálati helyen (29\%), esetleg egy eltérő szakmai területen (23\%), a kitöltők 42\%-a pedig 5 éven belül valamilyen szintủ vezetői feladatokra vágyik.

Összefoglalva, a kutatási eredményeink részben alátámasztják, részben pedig nem igazolják az általunk felvetett hipotéziseket.

$\mathrm{Az}$ első feltételezésünk (H1A) szerint az $\mathrm{Y}$ és $\mathrm{Z}$ generációs fiataloknak új igényei vannak a NAV-val kapcsolatban, amihez a munkáltatónak alkalmazkodnia kell, még ha egy közigazgatási szerv esetében szúkösek is a keretek. Azt is valószínúsítettük, hogy a NAV-ban elhelyezkedő fiatalokat valóban nem a munkahely biztonsága, illetve a kiszámítható lehetőségek motiválják leginkább (H1B). Az illetmény mellett olyan szervezeti intézkedéseket várnak el a munkaadótól, ami biztosítja számukra az egyéni fejlődés lehetőségét, a munka és magánélet egyensúlyát, a karriert, a jó munkakörülményeket, ideértve az atipikus, rugalmas munkavégzési formákat és az infrastrukturális fejlesztéseket is. Ezen túl örülnek a fiatalok, ha a kollégákkal és a vezetőkkel való együttmüködésük gördülékeny, a vezetők támogató hozzáállással bírnak, és folyamatos visszacsatolást adnak a munkájukkal kapcsolatban.

Feltételeztük továbbá (H2), hogy a munkahelyváltásra elsősorban a magasabb illetmény reményében kerül sor, és jellemzően a magánszektorban helyezkednek el a kollégák. Ez részben igazolódott, hiszen valóban a magánszektor felé orientálódnak a távozók, de elsősorban nem a magasabb illetmény miatt váltanak, hanem egyenletesebb munkaterhelést várnak el, ami biztosítja számukra a munkaidő és a szabadidő összhangját is. 
A kutatás kezdetén úgy véltük, hogy a munkahelyváltásra jellemzően a szerződésben vállalt három év leteltét követően került sor (H3A). Ez az állítás szintén nem igazolódott, hiszen a NAV-ot elhagyó válaszadók többsége három éven belül váltott munkahelyet, viszont ezt a szándékot a többség esetében befolyásolta az a tény, hogy nem arra a szolgálati helyre/szakterületre/munkakörbe kerültek, ahová szerettek volna (H3B), és amit a végzettségük, felkészültségük alapján reméltek.

\section{Javaslatok}

A kutatási eredmények alátámasztják a pénzbeli ösztönzők fontosságát, valamint a munka-magánélet egyensúlyának, a munkakörülményeknek a javítását, a képzési, fejlesztési lehetőségek körének bővítését, a vezetők „érzékenyítését”, szemléletés gondolkodásmódjának változtatását, illetve az életpályamodell és az előmeneteli rendszer reformálását.

A kérdőívet kitöltők közül sokan vállalták azt is, hogy az egyetlen szabadon megválaszolható kérdésünkre is reagálnak, és megfogalmazzák véleményüket a NAV munkaerő-megtartó képességét érintően. Összességében úgy vélik, hogy a NAV-nak nagyon csekély motiváló ereje van, de ez elmondható a többi közigazgatási és fegyveres szervrôl is. Leírták továbbá, hogy ha a NAV nem tud változtatni a jelenlegi szervezeti múködésén, leginkább az életpályán és az előmeneteli rendszeren, akkor „egyre több lesz a felmondás/leszerelés, illetve senki sem fog jelentkezni új munkavállalóként”.

Részletezve a fentieket, az alábbi javaslatok megfontolását tarjuk szükségesnek a fiatal generáció megtartása érdekében:

- A munkatársak elégedettségének és elkötelezettségének folyamatos vizsgálata (akár évente/félévente), elemzése, értékelése, a kollégák felé az eredmények korrekt és pontos visszajelzése. Ez generációktól függetlenül is fontos ahhoz, hogy a munkaerő megtartása érdekében célzott intézkedéseket hozzon a NAV. De különösen kiemelt ennek vizsgálata a fiatalok esetében, hiszen ők nem várnak évekig, hogy megkérdezzük véleményüket, és megfelelő lépéseket tegyünk, ösztönözve a szervezetben maradásukat. Ebben a kérdésben a magánszféra szervezetei, de sok közigazgatási szerv is rendelkezik már tapasztalattal. Több helyen készítenek úgynevezett „belépési”, „megtartó vagy motivációs” és „kilépési” interjúkat, felméréseket a munkatársakkal, jó volna ezeknek a tevékenységeknek a humán terület működésébe való integrálása.

- A jelenlegi életpályamodellből adódó konfliktusok/feszültségek lehető legrövidebb időn belüli megszüntetése. A mai NAV-os életpályamodell - a válaszadók szerint - „elvesztette versenyképességét, nem vonzó a munkát keresők körében”. „Csak részben oldotta meg a problémákat, illetve újabbakat generált. A feladata az lett volna, hogy a bérfeszültséget és az elvándorlást csökkentse és/vagy megszüntesse, azonban ezzel szemben növelte ezt.” Az előmeneteli feltételek kiüresedtek, a bérfeszültség még nagyobb lett, főleg a nyomozati szakterület és a vámszakterület között, amely jellemzően a közszolgálati 
pótlékbeli eltéréseknek „köszönhető”. Ebben a tekintetben érdemes lenne a fiatalok számára oly vonzó versenyszférát megvizsgálni és egy a felelősségi körhöz, a munkaterheléshez igazodó, elfogadható és tervezhető életpályát teremteni. Hiszen a NAV versenytársait elsősorban nem a közszférában és rendvédelmi szervek közt kell keresni, tekintettel a tudásra, amellyel a munkavállalók 3-5 év után rendelkeznek, hanem elsősorban a versenyszféra területén, mint ahogyan ezt a kutatásunk is igazolja.

- A válaszadók szerint a biztos anyagi háttér megteremtése mellett, komoly figyelmet kell szentelni annak, hogy az Y és $Z$ generációs fiatalok a munka és a magánélet összhangjára vágynak, amelynek biztosítása csak arányos munkaterheléssel, az adminisztráció csökkentésével, a munkafolyamatok egyszerűsítésével, arányos munkamegosztással, a valós munkaidő betartásával és a szabadidő kiadásával lehetséges.

- A pályakezdő fiatalok úgy vélik, hogy a szervezeti múködés és a munkaerőmegtartás kulcsa a legtöbb esetben a közvetlen vezető, akinek megfelelő rálátással és szakmai tudással kell rendelkeznie. Ezen túlmenően azonban azt is kiemelték, hogy a vezetők szemléletmódját és hozzáállását is fejleszteni kellene, leginkább a munkatársakkal való kommunikáció, a folyamatos viszszajelzések (például teljesítményértékelés), illetve az eredmények és a jó teljesítmény elismerése terén (itt nem elsősorban az anyagi elismerésre gondolunk). Fontos lenne továbbá arra is érzékenyíteni a vezetőket, hogy az Y és $Z$ generáció munkahellyel, feladatokkal, körülményekkel kapcsolatos elvárásai a korábbi generációkhoz képest változtak, és új típusú motivációs eszközök alkalmazását igénylik (például munkaköri rotáció, atipikus munkavégzési formák, fordított mentorálás stb.)

- Ahogyan azt a szakirodalmi elemzések és a kutatások is igazolták, ezen fiatalok számára nagyon fontos az egyéni fejlődési lehetőség biztosítása (szakmai és egyéni kompetenciák fejlesztése). Kapcsolódva az előző pontban felvetett javaslathoz, akár a teljesítmény elismerésével is összeköthető lenne a fejlesztés, ha a legjobb teljesítményt nyújtók az általuk leginkább preferált képzési lehetőségeket vehetnék igénybe (kompetenciafejlesztő tréning, nyelvtanfolyam, informatikai képzés, vezetők esetében coaching stb.) Persze, emellett az is fontos lenne, hogy ne csak a teljesítményelvárások körében szerepeljenek a munkatársaktól elvárt kompetenciák, hanem, ha ennek hiányát tapasztalják a vezetők, legyen lehetőségük a kollégáknak ezek fejlesztésére, a vezetők pedig támogassák ezt.

- Fentebb már többször is kiemeltük, hogy ennek a generációnak az egyik legfontosabb munkahelyi elvárása, hogy jól múködő közösségben, példamutató vezetőkkel és együttmúködő kollégákkal dolgozhasson. A szabadon megválaszolható kérdés keretében többen is jelezték, hogy ennek megteremtéséhez jó alapot adhatna, ha évente egyszer vagy kétszer lehetőségük lenne a szer- 
vezeti egységeknek arra, hogy egy-két napos csapatépítő tréningen vehessenek részt és a munkahelyen kívül is megismerjék egymást.

- A válaszadók véleménye alapján az utolsó javaslatunk a képzésben részt vevő oktatóknak szól. A volt hallgatók úgy érzik, hogy az egyetemen nem festenek reális képet a szervezetről, álomvilágba ringatják őket azzal, hogy „ennél a szervezetnél megbecsült emberek lesznek, és a végzettségükhöz méltó munkát fognak kapni”. Szerintük „az NKE nem a valóságról szól, csupán egy idilli helyzet képét vetíti ki a mit sem tudó hallgató szeme elé. Ezt követően, mikor lépni szeretne, már jó kis adósságba verte magát, amiből nem tud szabadulni egy könnyen." Úgy gondoljuk, hogy ez előbbiek ismeretében mindenképpen szükséges lenne a tanulmányiösztöndíj-szerződés felülvizsgálata, annak érdekében, hogy a szervezeti és egyéni érdekek mindinkább közelebb kerüljenek egymáshoz. A hallgató számára egyfajta biztonságot jelentsen a szerződés aláírása, természetesen megfelelő garanciákkal a munkáltató irányába is. Emellett fontosnak tarjuk, hogy a diploma megszerzését és a kinevezést megelőzően olyan egyéni elbeszélgetésekre (utalva a fentebb említett „belépési interjúra”) kerüljön sor a szakmai, a humánigazgatási és az oktatási vezetők, illetve a hallgatók között, amelyek segíthetik az igények és az elvárások kölcsönös kielégítését.

A javaslatok megvalósítása nyilvánvalóan a szervezet költségvetési kereteitől és a jogszabályi lehetőségektől is függ, viszont a fenti felvetéseink között több olyan is szerepel, amely elsősorban nem pénzügyi fedezet kérdése. A legtökéletesebb munkaerőmegtartást segítő eszközök megtalálása érdekében pedig nélkülözhetetlennek tartjuk e témakör további vizsgálatát, más szervezetek esetleges jó gyakorlatainak megismerését.

\section{IRODALOMJEGYZÉK}

Csíkszentmihályi Mihály (1997): FLOW - Az áramlat. A tökéletes élmény pszichológiája. Budapest, Akadémiai Kiadó.

Csutorás Gábor Ákos (2016): Az Y generációs munkatársak megtartási lehetőségei a Központi Statisztikai Hivatalban. Pro Publico Bono - Magyar Közigazgatás, 1. sz. 92-106.

Erdős Ákos (2018): Alkalom vagy tervszerűség? A pénzügyőr tisztjelöltek pályára lépésének rövid vizsgálatáról. In Czene-Polgár Viktória - Zsámbokiné Ficskovszky Ágnes szerk.: Innováció, elektronizáció, tudásmenedzsment. Budapest, Magyar Rendészettudományi Társaság Vám- és Pénzügyőri Tagozata.

Gyökér Irén - Krajcsák Zoltán (2009): Az alkalmazotti elégedettséget és elkötelezettséget befolyásoló tényezők vizsgálata. Vezetéstudomány, 40. évf. 1. különszám. 56-61.

Kassai László (2017): A katonai szolgálatról általában. Vélemények a katonai jog világából. Budapest, Magyar Katonai Jogi és Hadijogi Társaság. Forrás: www.hadijog.hu/vkj/ (2019. 01. 10.)

Krajcsák Zoltán (2018): Az alkalmazotti elkötelezettség relatív fontossága a munka megváltozó világában. Vezetéstudomány, 49. évf. 2. sz. 38-44. DOI: https://doi.org/10.14267/VEZTUD.2018.02.04 
Kultalahti, Susanna - Viitala, Riitta Liisa (2014): Sufficient challenges and a weekend ahead - Generation Y describing motivation at work. Journal of Organizational Change Management, Vol. 27, No. 4. 569-583. DOI: https://doi.org/10.1108/JOCM-05-2014-0101

Magasvári Adrienn - Szakács Édua (2018): Entrants at the gate of public service, or how do public service organizations see young people's career choice motivations. In Czene-Polgár Viktória - Zsámbokiné Ficskovszky Ágnes szerk.: Innováció, elektronizáció, tudásmenedzsment. Budapest, Magyar Rendészettudományi Társaság Vám- és Pénzügyőri Tagozata. 184-204.

Magasvári Adrienn (2018a): A Nemzeti Adó- és Vámhivatal hivatásos állományának jogviszonyára vonatkozó általános szabályok. In Erdős Ákos szerk.: Integrált pénzügyőri ismeretek I. Kezdő pénzügyőrök kézikönyve. Budapest, Magyar Rendészettudományi Társaság Vám- és Pénzügyőri Tagozata. 44-64.

Magasvári Adrienn (2018b): What is a good entrant into the labour market? Tudásmenedzsment, 19. évf. 2. sz. 123-130.

Meier, Justin - Crocker, Mitchell (2010): Generation Y in the Workforce - Managerial Challenges. The Journal of Human Resource and Adult Learning, Vol. 6. No. 1. 68-78.

Molnár Károly szerk. (1993): Katonaetika. Tanulmánygyújtemény. Budapest, Zrínyi Kiadó.

Pink, Daniel H. (2010): Motiváció 3.0 - Ösztönzés másképp. Budapest, HVG Kiadó Zrt.

Pregnolato, Monica - Bussin, Mark H. R. - Schlechter, Anton F. (2017): Total rewards that retain: A study of demographic preferences. SA Journal of Human Resource Management, Vol. 15, No. 2. 1-10. DOI: https://doi.org/10.4102/sajhrm.v15.804

Saxena, Parul - Jain, Rajiv (2012): Managing Career Aspirations of Generation Y at Work Place. International Journal of Advanced Research in Computer Science and Software Engineering, Vol. 2, No. 7. 114-118.

Smola, Karen - Sutton, Charlotte D. (2002): Generational differences: revisiting generational work values for the new millennium. Journal of Organizational Behavior, Vol. 23, No. 4. 363-382. DOI: https://doi.org/10.1002/job.147

Szabó, Andrea (2017): Objectives of the Bologna Process and their realization in the education of Hungarian Customs officers. Customs Scientific Journal, Vol. 7, No. 2. 54.

Szabó Andrea (2018a): A pénzügyőri képzésektől az adóigazgatási szakirányig. Belügyi Szemle, 66. évf. 11. sz. $71-80$.

Szabó Andrea (2018b): Sub pondere crescit palma, avagy a pénzügyőr tisztjelölt erőpróbája. In Dobák Imre - Hautzinger Zoltán szerk.: Szakmaiság, szerénység, szorgalom. Ünnepi kötet a 65 éves Boda József tiszteletére. Budapest, Dialóg Campus Kiadó. 601-602.

Vladár Anita (2016): A kiégés vizsgálata a munkahelyi elégedettség, a szervezeti elkötelezettség és a motiváció függvényében orvosok körében. Különleges Bánásmód, 2. évf. 3. sz. 15-29.

Wingfield, Barb - Berry, Janice (2001): Retaining Your Employees Using Respect, Recognition and Rewards for Positive Results. Crisp Fifty-minute book series, Crisp Publications Inc.

\section{Internetes források}

A global generational study, 2013. Summary and compendium of findings (2013). PwC's NextGen. Forrás: www.pwc.com/gx/en/hr-management-services/pdf/pwc-nextgen-study-2013.pdf (2019. 01. 10.)

Bezerédy Herald Balázs (2017): Employer Branding - a megtartás az új toborzás. Forrás: https://y2ycoaching.blog.hu/2017/06/22/employer_branding_a_megtartas_az_uj_toborzas (2019. 01. 10.)

Dajnoki Krisztina - Héder Mária (2017): „Új szelek fújnak” - a HR válasza a globalizáció és a változás kihívásaira. Hadtudomány, XXVII. évf. 84-93. Forrás: http://mhtt.eu/hadtudomany/2017/2017 elektronikus/dajnoki.pdf (2019. 01. 10.) DOI: https://doi.org/10.17047/HADTUD.2017.27.E.84

What if the next big disruptor isn't a what but a who? Gen $\mathrm{Z}$ is connected, informed and ready for business (2015). Ernst and Young Global. Forrás: www.ey.com/Publication/vwLUAssets/EY-what- 
if-the-next-big-disruptor-isnt-a-what-but-a-who/\$File/EY-what-if-the-next-big-disruptor-isnta-what-but-a-who.pdf (2019. 01. 10.)

www.ksh.hu/docs/hun/xftp/gyor/fog/fog1706.html (2019. 01. 10.)

\section{Jogforrások}

57/2009. (X. 30.) IRM-ÖM-PTNM együttes rendelet az egyes rendvédelmi szervek hivatásos állományú tagjai egészségi, pszichikai és fizikai alkalmasságáról, közalkalmazottai és köztisztviselői munkaköri egészségi alkalmasságáról, a szolgálat-, illetve keresőképtelenség megállapításáról, valamint az egészségügyi alapellátásról

73/2013. (XII. 30.) NGM rendelet a Nemzeti Adó- és Vámhivatalnál foglalkoztatottak alkalmassági vizsgálatáról, valamint a Nemzeti Adó- és Vámhivatal Képzési, Egészségügyi és Kulturális Intézete által nyújtott egészségügyi szolgáltatás igénybevételére jogosultakról

\section{ABSTRACT}

\section{A Specific Target Group Study about the Workforce Retention Capability of the National Tax and Customs Administration}

MAGASVÁRI Adrienn - SZABÓ Andrea

In recent years, a number of conferences, lectures, and studies have been devoted to examining the organisations' ability in retaining their workforce. According to experiences, both private and public sectors are highly exposed to challenges such as the reorganisation of the labour market, the international migration of the workforce, handling intergeneration problems, and understanding the needs of new generations, etc. This study explains the results of a survey where respondents were students graduated between 2012-2017 at the Law Enforcement Faculty of the National University of Public Service. Each of them graduated as customs officers and benefited from the support of the National Tax and Customs Administration (NCTA) during their studies and also, this is the agency where they started their careers. On the one hand, this article focuses on junior customs officers who have already collected service experiences for a few years, and is inquisitive how they see their own organisation facing HR challenges in retaining their workforce, and the reasons why certain staff members intend to change. On the other hand, these lessons learnt might also allow the organisation the estimation of how long they can count on these young people.

Keywords: generations, motivation, replacement 